\title{
Estimation of Reminant Gold Resources of Old Underground Workings by Indicator Approach - A Case Study*
}

\author{
S. Al-Hassan, and L. Aboagye
}

Al-Hassan, S. and Aboagye, L. (2008). "Estimation of Reminant Gold Resources of Old Underground Workings by Indicator Approach - A Case Study”, Ghana Mining Journal, pp. 30 - 37.

\begin{abstract}
The lack of geological control and old underground development at AngloGold Ashanti (Bibiani mine) in Ghana was a major setback for the conventional methods of resource estimation to produce accurate estimates of the deposit. Consequently, inverse distance weighting of indicator variables were used. This estimation approach, however, overestimated the boundaries of the old underground workings (voids) into inappropriate areas of the resource model and thereby caused significant underestimation of ore tonnage and overestimation of grade.

This paper highlights the study that re-evaluated the Bibiani deposit using indicator kriging. The results of re-evaluated reserves compared well with actual production figures in terms of tonnes, grade and stoping volume.
\end{abstract}

\section{Introduction}

AngloGold Ashanti (Bibiani mine) is located about $380 \mathrm{~km}$ by road, northeast of Accra (Fig. 1). The climate in the area is wet semi-equatorial characterised by annual double maximum rainfall pattern occurring in the months of March to July and from September to mid-November. The annual rainfall varies from year to year with a mean of about 1 $473 \mathrm{~mm}$.

The first recorded mining operation at the Bibiani mine was in 1902 (De Vente, 2002). However, the mine was closed down in 1968 due to lack of mineable reserves. After the change of ownership and further exploration, the mine was resuscitated in 1997. Open pit mining method was used without any detailed plans to indicate stopes, high grade, broken ore and pillars underground. This, in addition to little geological control, did not allow the conventional method of resource estimation to produce reliable estimates for the remnant gold resources. This called for a review of the resource estimation model. It was imperative to re-evaluate the Bibiani resources using an alternative approach to ascertain whether the consistent overestimation encountered by the conventional Inverse Distance Weighting (IDW) method could be significantly reduced.

This paper is the outcome of the research that reevaluated the Bibiani resources using indicator kriging and an unconstrained estimation for lithology. The results of the research work compare well with the actual production figures from grade control in terms of stoping volume, tonnes of ore and grade.

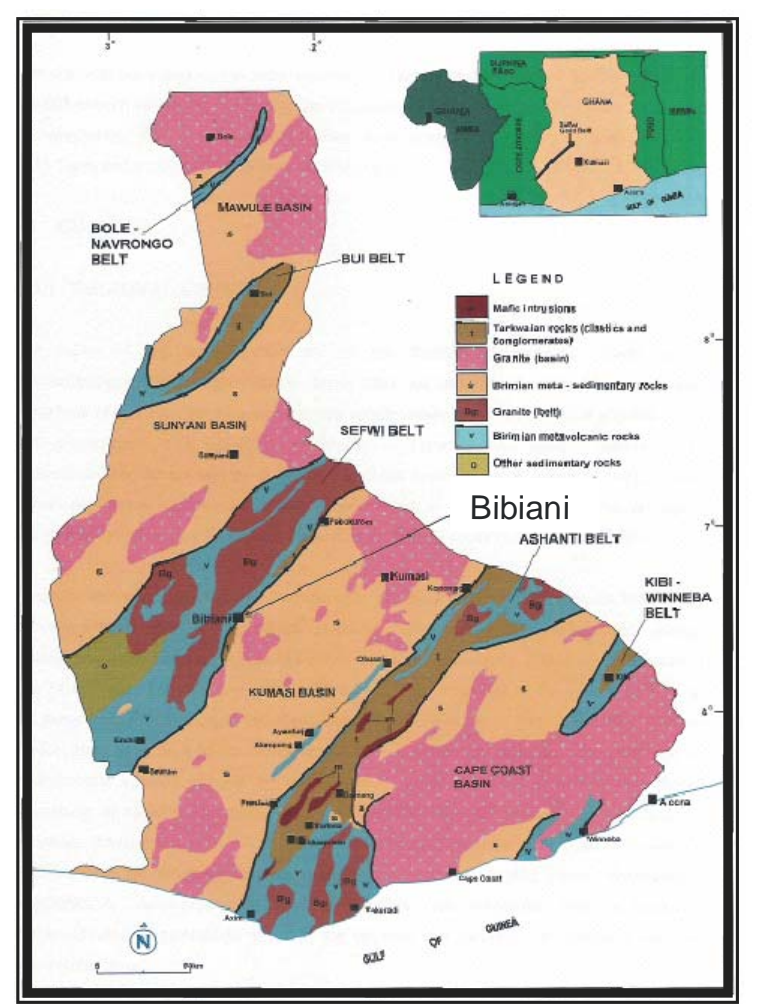

Fig. 1 Location of Bibiani

\section{Local Geology}

The local geology of the mine has features that are typical of Birimian gold deposits. The host rocks for the gold mineralization are quartz veins, metavolcanic, volcaniclastic and metasedimentary rocks (Fig. 2). 


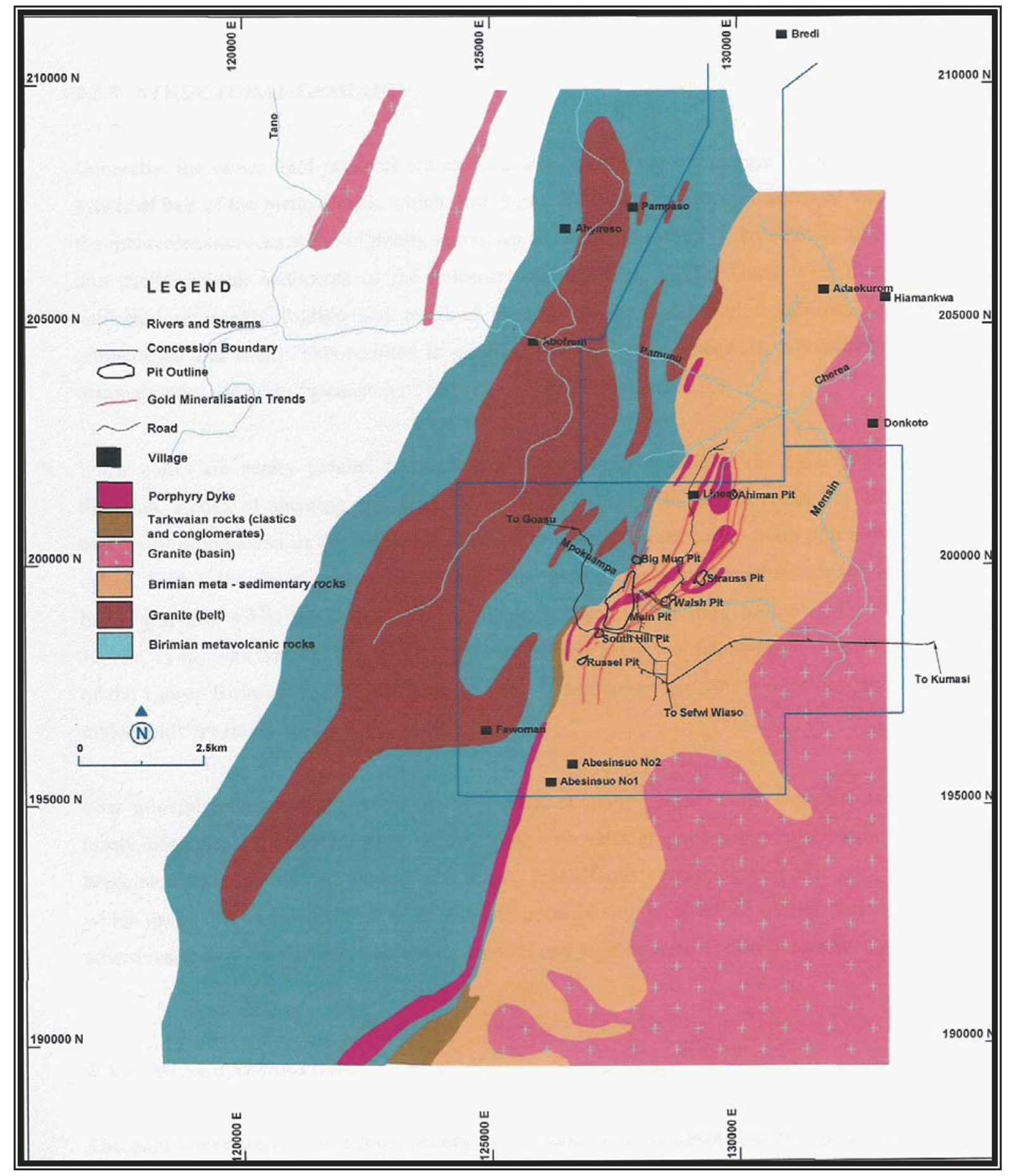

Fig. 2 Plan of Bibiani Geology Showing Trend of Gold Mineralisation.

The quartz veins are developed on a shear zone which trends parallel to the belt but with dips slightly flatter than the host rocks and parallel to axial plane cleavage. Gold mineralization often shows close spatial relationship to zones of alteration such as carbonation, sericitisation and silicification (Leube et al, 1990).

Two types of auriferous ore bodies may be identified as (Leube et al., 1990):

1. Disseminated sulphide type (DST) that is either lithofacies controlled, regional in extent and syngenetic in origin (DST1) is associated with the salvage of quartz veins and is epigenetic (DST2).

2. Quartz vein type (QVT) of local gold mineralisation that is structurally controlled and epigenetic in origin.

\section{Data Collection and Analysis}

Data from 357 holes involving reverse circulation 
and diamond drilling holes totalling $5.86 \mathrm{~km}$ was collected. About half of the drilling and the bulk of the deeper holes were carried out by diamond coring in HQ, NQ and BQ sizes. Each diamond drill core was sampled by conventional splitting using a diamond saw. For low grade intersections, the sample interval was $3 \mathrm{~m}$. However, this was reduced to $1.5 \mathrm{~m}$ or less in high grade areas. Geological control has been a more important factor in deciding on sampling intervals for the later holes with BQ cores.

The data was input into the spreadsheet and saved in four files namely: assay, lithology, downhole survey, and collar. The database was validated for irregularities in the form of missing information such as illogical data entries and overlaps of sample intervals.

Analysis of the data was aided by surface geological maps (including structural maps) at a scale of 1:2500 and mnemonic lithological codes which make the data tractable for resource modelling (Speijers and Macdonald, 1996).

\section{Orebody Modelling}

Sectional interpretations were digitised in crosssectional views at appropriate intervals along

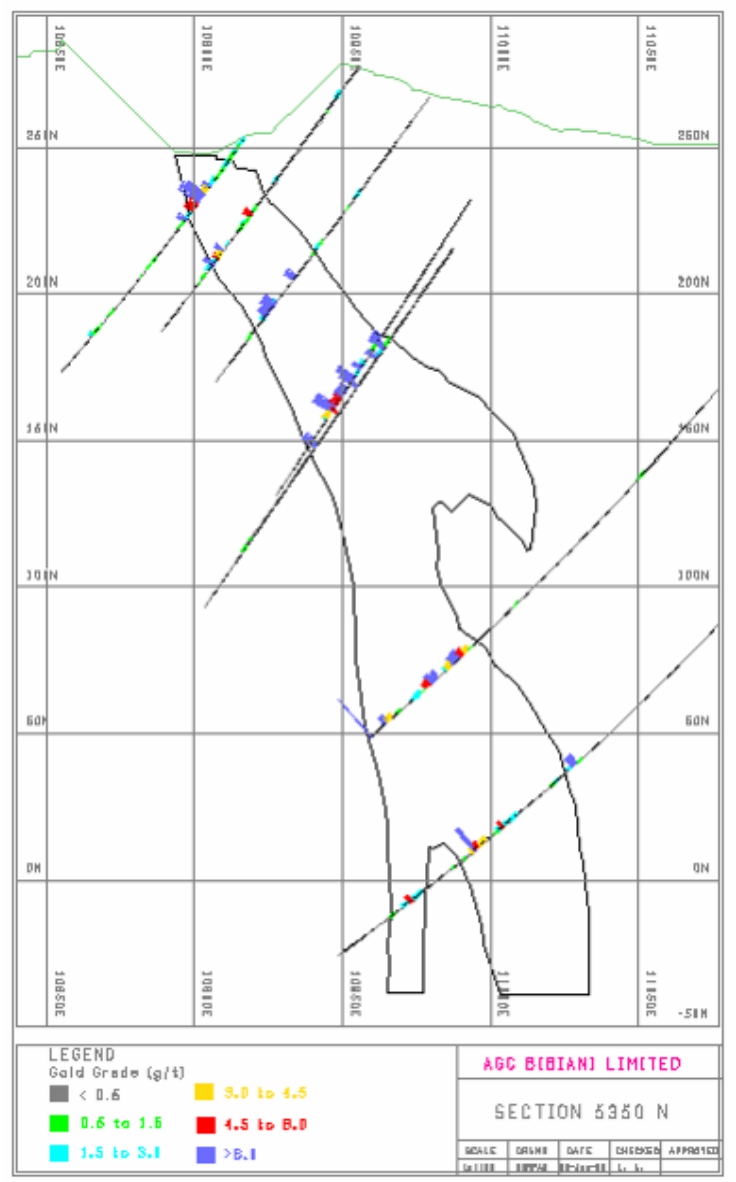

Fig. 3 Typical Section through the Orebody along $5350 \mathrm{~N}$ strike of the orebody. An example of such cross section along $5350 \mathrm{~N}$ is shown in Fig. 3. The envelopes around the mineralised zone were drawn with a cut-off grade of $0.5 \mathrm{~g} / \mathrm{t}$ for oxide and $0.7 \mathrm{~g} / \mathrm{t}$ for primary material. However, some material with gold grades below these cut-offs were unavoidably included in some places to give a continuous smooth geometry.

The sections of each ore type were linked from one section to the next to form a three dimensional wireframe solid of the mineralisation covering the entire strike from $4650 \mathrm{~N}$ to 1690 N. Fig. 4 shows the isometric view of the wireframe model when looking above towards northwest.

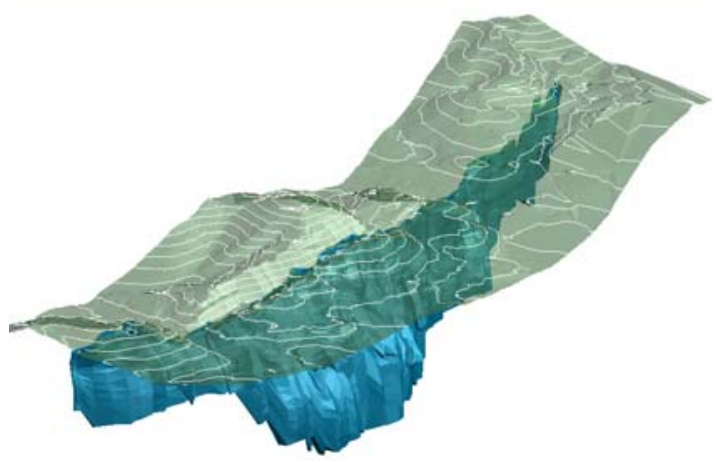

Fig. 4 Wireframe Model of the Orebody

\section{$5 \quad$ Sample Compositing}

Samples falling within each lithological unit and ore-type in the wireframe were selected and composited to $2 \mathrm{~m}$ length downhole for grade. A threshold length of acceptance was set to 75\% (1.5 $\mathrm{m})$. Any composite sample of length less than 1.5 $\mathrm{m}$ was discarded. For statistical analysis, it is required that the same support is used, otherwise any statistic, apart from the mean, will be statistically unrepresentative and meaningless (Marsal, 1987). Drill hole data for lithology estimates was not constrained to the limits of the wireframe models. Samples were composited to $2.0 \mathrm{~m}$ downhole intervals from top to bottom of holes.

\section{Statistical Analysis}

The samples from the different drill types were tested statistically to verify if they come from identical populations using Analysis of Variance (ANOVA) method. The tests at 5\% level of significance indicated that they come from identical populations and suggested that the samples from the different drill campaigns could be combined.

The sample statistics of the retrieved composites gold grade for each lithological unit within the wireframe were studied. An example of the histograms of their distributions is shown in Fig. 5 


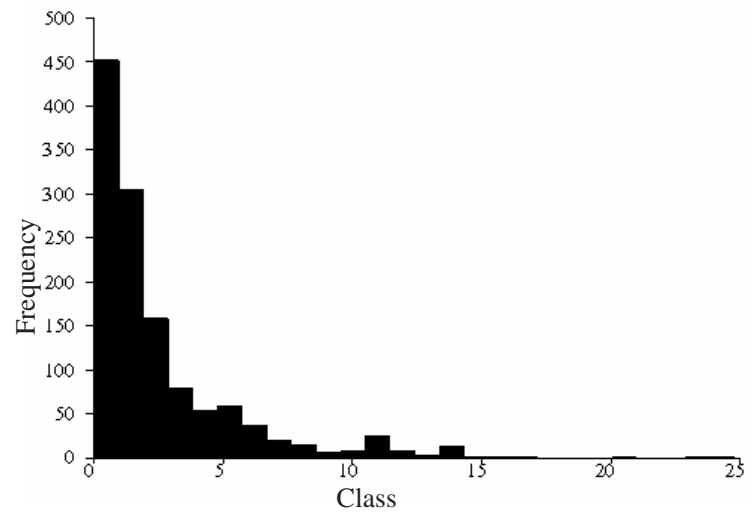

Phyllite_Au_Composite (raw)

Fig. 5 Histogram of Phyllite Composite Assays

\section{Geostatistical Analysis}

\subsection{Variography}

Indicator flag fields were set for both lithology and gold composite groupings for variogram analysis. To reduce the effect of smoothening on estimates into inappropriate areas of the deposit due to strike change, the data was classified into two domains namely the south and north (along $5800 \mathrm{~N}$ grid).

Lag spaces of $25 \mathrm{~m}$ and $2 \mathrm{~m}$ were used for the horizontal and vertical semi-variograms respectively. Experimental semi-variograms were calculated on incremental angles of 25 degrees with angular tolerance set to 5 degrees to allow for ade quate data capture to generate representative struc-

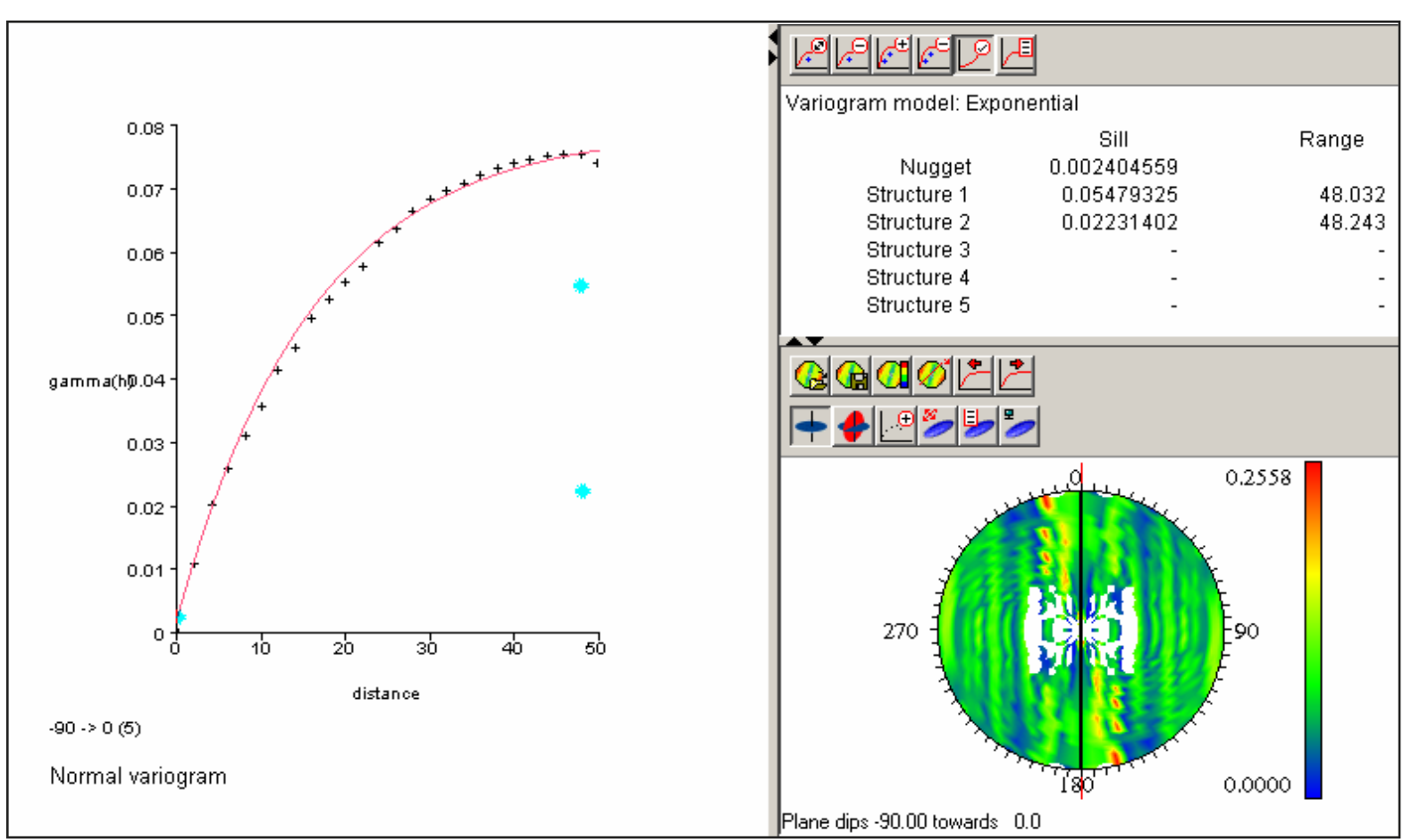

all analysis.

The exponential model was found to give the most appropriate fit to the indicator experimental variograms for the Bibiani deposit. Subsequently, the exponential model was used to model both lithology and gold grade indicators. A typical semi-variogram is shown in Fig. 6.

Considering the five lithology indicators and gold grade indicators for the 7 grade groupings within the south and north data domains, 61 individual variogram analyses were carried out.

\subsection{Indicator Modelling}

Indicator model was used to obtain the proportion of a particular lithology and grade category (bin) for a particular block of the deposit. The lithological codes in the drillhole database were grouped. Old underground workings were considered as a fifth lithology called stope (ST). The five groups are shown in Table 1. All drillhole intersections were then checked for missing lithological information. Intervals without any lithological code were assigned the code 'PH' for phyllite which is the most predominant rock.

To provide a geological constraint on the subsequent grade model, a probabilistic model was created using the following steps:

i. A set of flag fields were created for the unconstrained drillhole data with one field for each lithology including stopes. These fields

Fig. 6 An Exponential Model Fitted to Downhole Experimental Semi-variogram for Phyllite Stockwork in Bin 4. 
were all initialized to zero

ii. For each downhole interval the flag field corresponding to the actual lithology code for that interval was set to a value of 1 ; all other flag fields keep a value of zero.

iii. The five flag fields were then composited into 2 meter long downhole intervals so that each two-metre interval contained a value between 0 and 1, representing the length proportion of the lithology in question.

iv. Geostatistical analysis was carried out for the flag fields. Each of the five flag fields was analysed separately as presented in Appendix A.

v. Using the indicator variables established in step iv, the flog fields were interpolated to give a value between 0 and 1 for each field in each block.

vi. The five fields in the model were standardised so that they summed to 1 . The grade was estimated for each of the lithologies in turn with the exception of stopes in a similar approach.

vii. Seven grade intervals, called bins, were selected for each lithology, covering the range of assay values present. The grade ranges used were based on the 16, 30, 44, 58 and 72 and 86 percentiles of the frequency distribution estimated from the normal probability plots. The limits of the bins were carefully selected to give approximately equal data points within the various grade classes. The grade ranges are given in Table 2 .

viii.For each lithology a set of seven flag fields were created, one for each grade bin. All 28 flag fields were initialized to a value of zero.

\subsection{Grade Model}

The proportion of each lithology grade bin in each block was estimated as follows:

i. Considering each uncomposited downhole interval in turn, the assay value and the lithology code were noted and a value of 1 was set in the bins with lithology and grade bin corresponding to those values.

ii. The seven bins for each of the lithlogies were then composited into 2 meter length downhole intervals so that each composite interval for each field contained a value between 0 and 1 that is the length proportion of the grade bin in question.

iii. Geostatistical analysis was carried out for the seven bins in each lithology to establish model parameters for estimation. Each of the seven bins for the lithologies within each data domain was analysed separately. There was a total of fourteen variogram analysed for each of the four lithlogies. Fig. 6 shows a typical case of such semi-variograms.

iv. Considering each lithology in turn, each flag field value was estimated into the block model using the corresponding model parameters. Separate estimations were carried out for blocks lying within the south and north data domains. However, the data values were not constrained to their respective domains. A total of 56 interpolations were carried out for the four lithologies.

v. The estimated flag field values in each block were normalized so that they summed to 1 for each lithology. The flag field values then correspond to the expected proportion of the associated grade bin at that location. The individual flag field values were then applied

Table 1 Search Parameters

\begin{tabular}{|l|c|c|c|c|c|c|c|c|c|}
\hline \multicolumn{1}{|c|}{ Lithology } & Search & Min & Max & Search & Bearing & Plunge & Dip & \multicolumn{2}{|c|}{ Anisotropy Ratios } \\
\cline { 5 - 9 } & Strategy & Samples & Samples & Radius & & & & Major/Semi & Major/Minor \\
\hline Quartz Vein & Ellipsoid & 2 & 24 & 75 & 265 & 85 & 0 & 1 & 3 \\
Phyllite Stockwork & $"$ " & 2 & 24 & 75 & 260 & -85 & 0 & 1.4 & 2.5 \\
Phyllite & $"$ " & 2 & 24 & 65 & 0 & 0 & -90 & 1.2 & 2.3 \\
Porphyry & $"$ " & 2 & 24 & 95 & 5 & 0 & -90 & 3.3 & 5.2 \\
Stope & " " & 2 & 24 & 80 & 175 & 0 & 80 & 1.1 & 2.4 \\
\hline
\end{tabular}

Table 2 Indicator Grade Bins

\begin{tabular}{|c|l|l|l|l|l|l|l|}
\hline $\begin{array}{c}\text { Lithology } \\
\text { Code }\end{array}$ & \multicolumn{7}{|c|}{ Gold Grade Ranges (g/t) } \\
\cline { 2 - 8 } & Bin1 & Bin2 & Bin3 & Bin4 & Bin5 & Bin6 & Bin7 \\
\hline QV & $<0.9$ & $0.9-1.7$ & $1.7-2.6$ & $2.6-3.7$ & $3.7-5.6$ & $5.6-11.9$ & $>11.9$ \\
\hline $\mathrm{PS}$ & $<0.9$ & $0.9-1.4$ & $1.4-2.1$ & $2.1-2.8$ & $2.8-4.2$ & $4.2-6.1$ & $>6.1$ \\
\hline $\mathrm{PH}$ & $<0.3$ & $0.3-0.7$ & $0.7-1.2$ & $1.2-1.8$ & $1.8-2.8$ & $2.8-5.1$ & $>5.1$ \\
\hline $\mathrm{PY}$ & $<0.4$ & $0.4-0.8$ & $0.8-1.1$ & $1.1-1.4$ & $1.4-2.2$ & $2.2-4.2$ & $>4.2$ \\
\hline
\end{tabular}


to the mean grade values of the associated bins and summed to give an expected grade of each block in a particular lithology. For the uppermost bin, the median grade values were used because no assay top-cuts were applied. Appendix A is a summary statistics of the bin grades for each of the lithologies.

vi. On completion of the normalization for each of the lithologies, the expected average grade of a block as a whole was calculated by summing the products of the individual lithology proportions and their respective estimated grades. An example of the grade estimation procedure is provided in Appendix B.

\section{Modelling Strategy}

Block dimensions of 15 x 6 x 6 m were used. For boundary resolution a cell split into two was adopted. The model prototype is shown in Table 3. Search ellipsoids were used with appropriate radii corresponding with the anisotropies. Soft boundary conditions were allowed between the oxide, transition and primary material within each data domain.

\section{Model Validation}

The Bibiani deposit block model has been validated using visual examination of assay and estimated block grades in sections and plans. Block grades were compared spatially with input grades to ensure that grade trends were represented correctly in the block model. The trends seen in the block grades were consistent with those of the input data. Fig. 7 shows a typical cross-section through the blocks and the drill holes coloured on gold grade.

\section{Discussion of Results}

The results from IK are shown alongside those of IDW in Table 4 for comparison. For effective assessment of the propriety of IK and IDW methods in estimating the resources at Bibiani, their estimates were constrained with the wireframe of the mined out pit and topography where the data was obtained. Only materials, categorised as Indicated 1 and 2 were included in the reserves to conform to the Joint Ore Reserve Committee (JORC) Code. The global reserves within the pit perimeter are shown in Table 5.

The results show that IK and IDW underestimated the tonnage but IK estimates were better. The IK estimates also showed closer grade estimates to actual than IDW. The comparison is better illustrated by the grade-tonnage curves in Fig. 8. The underestimation of the tonnage is due to overestimation of the stope volume (void). Irregularity of the orebody, due to local broadening of the orebody, may also contribute to it. For the ore grade,
IK underestimated by $0.6 \%$ whilst IDW overestimated it by $6 \%$. The overall assessment indicates that the IK model compares better with the actual than the IDW estimates for both grade and tonnage.

Table 3 Block Model Framework

\begin{tabular}{|c|c|c|c|c|}
\hline & $\begin{array}{c}\text { Model } \\
\text { Limit (m) }\end{array}$ & $\begin{array}{c}\text { Cell Size } \\
(\mathbf{m})\end{array}$ & $\begin{array}{c}\text { No. of } \\
\text { Cells }\end{array}$ & $\begin{array}{c}\text { Sub-cell } \\
\text { Size (m) }\end{array}$ \\
\hline East - West & $10501.5-11281.5$ & 6 & 130 & 3 \\
North - South & $4720-6715$ & 15 & 133 & 7.5 \\
Vertical & -378 & 6 & 63 & 3 \\
\hline
\end{tabular}

Table 4 Resource Estimation Results

\begin{tabular}{|c|c|c|c|c|c|c|}
\hline \multirow[b]{2}{*}{ Type } & \multicolumn{3}{|c|}{ IK } & \multicolumn{3}{|c|}{ IDW } \\
\hline & $\begin{array}{c}\text { Tonnage } \\
\left(10^{6}\right)\end{array}$ & $\begin{array}{c}\text { Grade } \\
(\mathrm{g} / \mathrm{t})\end{array}$ & $\begin{array}{c}\text { Ounces } \\
\left(\mathbf{1 0}^{6}\right)\end{array}$ & $\begin{array}{c}\text { Tonnage } \\
\left(10^{6}\right)\end{array}$ & $\begin{array}{c}\text { Grade } \\
(\mathrm{g} / \mathrm{t})\end{array}$ & $\begin{array}{c}\text { Ounces } \\
\left(\mathbf{1 0}^{6}\right)\end{array}$ \\
\hline Indicated 1 & 10.4 & 3.53 & 1.18 & 9.6 & 3.75 & 1.16 \\
\hline Indicated 2 & 6.8 & 2.54 & 0.55 & 6.1 & 2.49 & 0.49 \\
\hline Inferred & 2.8 & 2.41 & 0.22 & 2.5 & 2.1 & 0.17 \\
\hline
\end{tabular}

Table 5 Reconciliation of Reserves

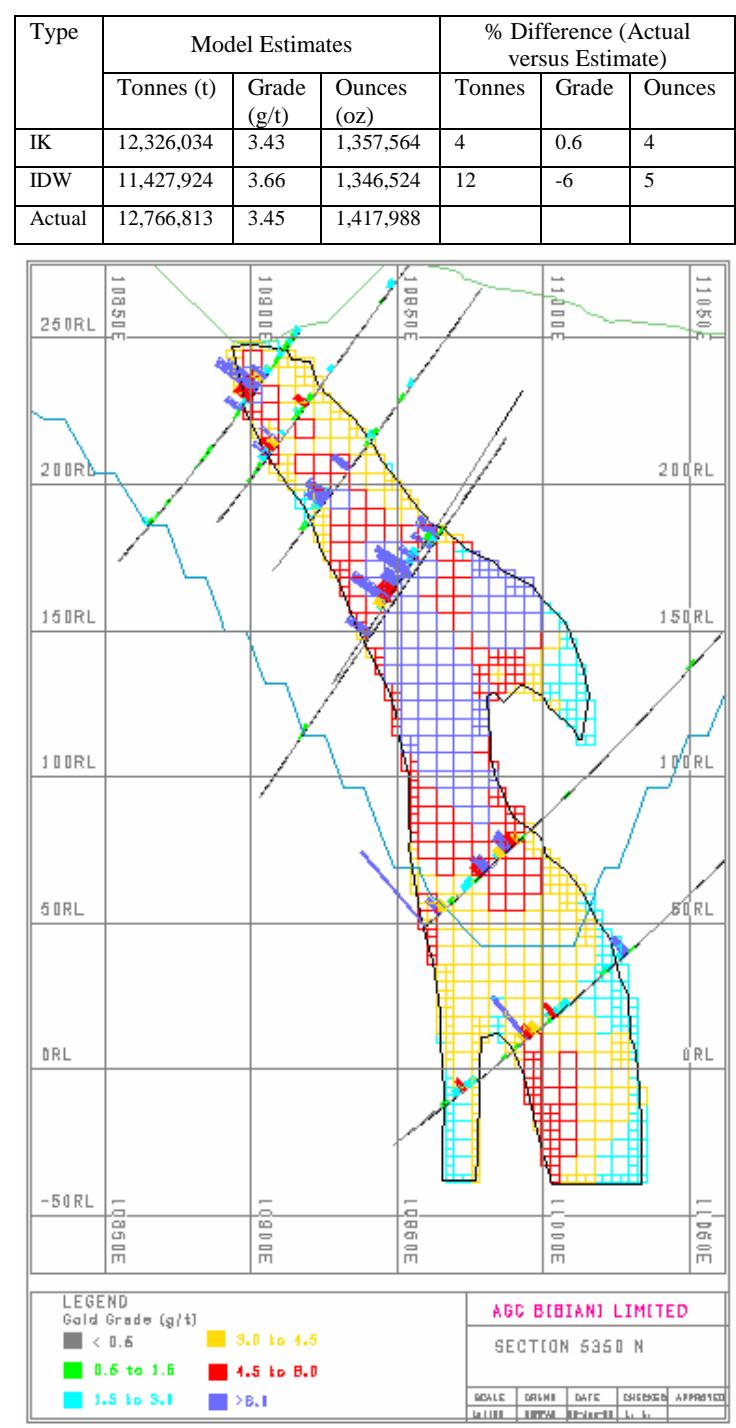

Fig. 7 Cross-section of the Bibiani Resource Model at 5650 Northing 


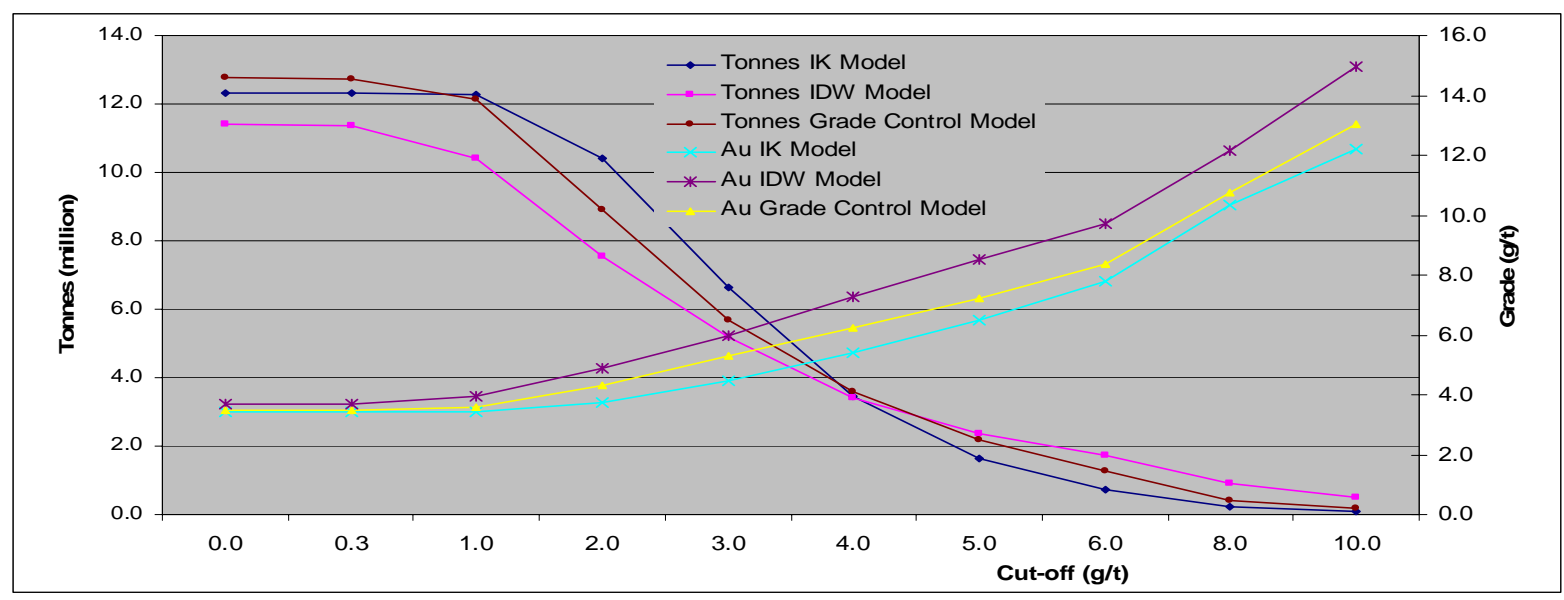

Fig. 8 Grade-Tonnage Curves for the IDW, IK and Actual Resources

\section{Conclusions}

The following conclusions are made from the analysis of the results:

i. Indicator algorism provides acceptable variable in estimating voids and lithology. The use of indicators also limits the undue influence of high grade values on grade estimates.

ii. In the absence of comprehensive underground plans IK provides better estimates than IDW.

iii. Comparison of IDW and IK against actual production values indicates that the IK model compares more favourably with the actual production figures than that of IDW for both grade and tonnage.

iv The IDW model overestimates the grade of the remnant gold resources. This is due to the inability of IDW to adequately deal with data clustering. The inappropriate estimation of stoping volume segments of the orebody caused an underestimation of low grade tonnage with the net effect of the average gold grade being overestimated.

\section{Recommendations}

From the results work, it is recommended that the company could consider using the IK estimation technique in the re-evaluation of the mineral resources to enhance the economics of either the proposed underground or cut-back projects.

\section{Acknowledgement}

The authors are grateful to the management of Ashanti Goldfields Company for giving permission for their data to be used for this research and all the necessary support.

\section{References}

De Vente, C. (2002), “Annual Ore Resources and Reserve Statements”, A. G. C. Bibiani Lim ited, Bibiani, Ghana (Unpublished), pp 16 -
17.

Leube, A., Hirdes, W., Mauer, R., Kesse, G. O. (1990), "The early Proterozoic Birimian Supergroup of Ghana and some aspects of its associated Gold Mineralisation”. Pre cambrian Research, 46 (1990), Elsevier Science Publishers B. V., Amsterdam, Netherlands, pp. 139 - 165.

Marsal, D. (1987), Statistics for Geoscientists, Pergamon Press, Oxford, 119 p.

Speijers, M. and Macdonald, M. J. (1996), Techni cal Review and Estimation of Resources, A. G. C. Bibiani Limited, Bibiani, Ghana; pp. 308-310; 341-344.

Appendix A

Summary Statistics of Gold Grade Groupings

\begin{tabular}{|c|c|c|c|c|c|c|c|c|}
\hline \multirow[t]{2}{*}{ Lithology } & \multirow[t]{2}{*}{ Statistic } & \multicolumn{7}{|c|}{ Gold Grade Range (g/t) } \\
\hline & & $\operatorname{Bin} 1$ & $\operatorname{Bin} 2$ & $\operatorname{Bin} 3$ & $\operatorname{Bin} 4$ & $\operatorname{Bin} 5$ & $\operatorname{Bin} 6$ & $\operatorname{Bin} 7$ \\
\hline \multirow{7}{*}{$\begin{array}{c}\text { Quartz } \\
\text { Vein }(\mathrm{QV})\end{array}$} & Number & 100 & 84 & 78 & 85 & 84 & 84 & 84 \\
\hline & Mean & 0.370 & 1.316 & 2.139 & 3.117 & 4.561 & 7.900 & 26.589 \\
\hline & Variance & 0.077 & 0.058 & 0.078 & 0.108 & 0.325 & 2.953 & 676.171 \\
\hline & C.V & 0.749 & 0.183 & 0.130 & 0.106 & 0.125 & 0.218 & 0.978 \\
\hline & Min. & 0.000 & 0.900 & 1.710 & 2.609 & 3.700 & 5.620 & 11.900 \\
\hline & Median & 0.331 & 1.345 & 2.106 & 3.106 & 4.470 & 7.758 & 20.169 \\
\hline & Max & 0.888 & 1.692 & 2.596 & 3.684 & 5.583 & 11.790 & 218.000 \\
\hline \multirow{7}{*}{$\begin{array}{l}\text { Phyllite } \\
\text { Stockwork } \\
\text { (PS) }\end{array}$} & Number & 71 & 70 & 65 & 64 & 68 & 69 & 64 \\
\hline & Mean & 0.534 & 1.108 & 1.701 & 2.452 & 3.380 & 5.082 & 8.942 \\
\hline & Variance & 0.065 & 0.023 & 0.033 & 0.033 & 0.166 & 0.350 & 13.681 \\
\hline & C.V & 0.476 & 0.137 & 0.107 & 0.074 & 0.120 & 0.116 & 0.414 \\
\hline & Min. & 0.010 & 0.910 & 1.400 & 2.120 & 2.800 & 4.208 & 6.100 \\
\hline & Median & 0.560 & 1.100 & 1.703 & 2.503 & 3.325 & 4.948 & 7.980 \\
\hline & Max & 0.898 & 1.392 & 2.036 & 2.760 & 4.140 & 6.085 & 31.400 \\
\hline \multirow{7}{*}{$\begin{array}{c}\text { Phyllite } \\
\text { (PH) }\end{array}$} & Number & 182 & 186 & 184 & 183 & 173 & 176 & 171 \\
\hline & Mean & 0.109 & 0.492 & 0.960 & 1.496 & 2.220 & 3.898 & 8.833 \\
\hline & Variance & 0.008 & 0.013 & 0.021 & 0.031 & 0.078 & 0.577 & 11.541 \\
\hline & C.V & 0.836 & 0.235 & 0.151 & 0.118 & 0.126 & 0.195 & 0.385 \\
\hline & Min. & 0.000 & 0.300 & 0.700 & 1.200 & 1.808 & 2.800 & 5.140 \\
\hline & Median & 0.088 & 0.500 & 0.968 & 1.510 & 2.138 & 3.842 & 7.673 \\
\hline & Max & 0.286 & 0.697 & 1.195 & 1.798 & 2.798 & 5.096 & 23.840 \\
\hline \multirow{7}{*}{$\begin{array}{c}\text { Porphyry } \\
\text { (PY) }\end{array}$} & Number & 41 & 43 & 34 & 33 & 34 & 37 & 38 \\
\hline & Mean & 0.173 & 0.625 & 0.951 & 1.246 & 1.751 & 2.929 & 6.887 \\
\hline & Variance & 0.009 & 0.014 & 0.008 & 0.008 & 0.050 & 0.331 & 11.807 \\
\hline & C.V & 0.548 & 0.187 & 0.091 & 0.073 & 0.128 & 0.196 & 0.499 \\
\hline & Min. & 0.020 & 0.422 & 0.805 & 1.119 & 1.412 & 2.200 & 4.215 \\
\hline & Median & 0.174 & 0.635 & 0.948 & 1.244 & 1.698 & 2.685 & 5.841 \\
\hline & Max & 0.350 & 0.793 & 1.096 & 1.380 & 2.172 & 4.020 & 23.110 \\
\hline
\end{tabular}




\section{Appendix B}

\section{Example of Indicator Estimate of Gold Grades}

An example of an initial estimate of lithology proportions after kriging run is provided in the Table 1 . where IJK number is the cell identification number of the model and qv_prop, ps_prop, ph_prop, st_prop are attribute fields for lithology estimates explained in Table 5.8

The sum of the initial lithology estimate is not equal to 1.0. For an unbiased estimate of lithologies, the proportions must be normalized so that they sum equals 1.0.

The proportions are normalized by dividing each of the lithology proportions by the total to give a new set of values presented in the Table 2.

Table 1 Initial Estimate of Lithology Proportions

\begin{tabular}{|c|l|l|l|l|l|}
\hline $\begin{array}{c}\text { IJK } \\
\text { Number }\end{array}$ & qv_prop & ps_prop & ph_prop & py_prop & st_prop \\
\hline 145678 & 0.156 & 0.275 & 0.536 & 0.023 & 0.047 \\
\hline
\end{tabular}

Table 2 Normalised Estimated Values of Lithology Proportions

\begin{tabular}{|l|c|c|c|c|c|}
\hline $\begin{array}{l}\text { IJK } \\
\text { Number }\end{array}$ & qv_prop & ps_prop & ph_prop & py_prop & st_prop \\
\hline 145678 & 0.1504 & 0.2652 & 0.5169 & 0.0222 & 0.0453 \\
\hline
\end{tabular}

Table 3 Initial Estimates of Lithology Grade Bin Proportions

\begin{tabular}{|l|l|l|l|l|l|l|l|}
\hline & Bin 1 & Bin 2 & Bin 3 & Bin 4 & Bin 5 & Bin 6 & Bin 7 \\
\hline qv & 0.000 & 0.023 & 0.675 & 0.123 & 0.007 & 0.000 & 0.150 \\
\hline ps & 0.568 & 0.111 & 0.045 & 0.000 & 0.000 & 0.277 & 0.000 \\
\hline ph & 0.327 & 0.000 & 0.456 & 0.109 & 0.037 & 0.036 & 0.045 \\
\hline py & 0.000 & 0.000 & 0.000 & 0.000 & 0.000 & 0.000 & 0.978 \\
\hline
\end{tabular}

Table 4 Normalised Estimated Values of Lithology Grade Bin Proportions

\begin{tabular}{|l|l|l|l|l|l|l|l|}
\hline & Bin 1 & Bin 2 & Bin 3 & Bin 4 & Bin 5 & Bin 6 & Bin 7 \\
\hline qv & 0.0000 & 0.0235 & 0.6902 & 0.1258 & 0.0072 & 0.000 & 0.1534 \\
\hline ps & 0.5674 & 0.1109 & 0.0450 & 0.0000 & 0.0000 & 0.2767 & 0.0000 \\
\hline ph & 0.3238 & 0.0000 & 0.4515 & 0.1079 & 0.0366 & 0.0356 & 0.0446 \\
\hline py & 0.0000 & 0.0000 & 0.0000 & 0.0000 & 0.0000 & 0.000 & 1.0000 \\
\hline
\end{tabular}

An example of an initial lithology grade bin estimate for the cell after a kriging run is provided in the Table 3 . The grade bin proportions are also normalized so that they sum up to 1.0 to give new figures provided in Table 4.

Using the grade bin means provided in Appendix B for Bins 1 to 6 and the median for Bin 7, the grade of the proportion of each of the lithology within the model cell is calculated as follows:

$$
\begin{aligned}
& \text { Quartz vein grade }\left(\mathrm{au} \_\mathrm{qv}\right)=\mathrm{qv}_{\mathrm{bin} 1} * \mathrm{Au}_{\mathrm{bin} 1}+\mathrm{qv}_{\mathrm{bin} 2} * \mathrm{Au}_{\mathrm{bin} 2}+ \\
& \text {..... qubin7*Aubin7 } \\
& =0.0 * 0.370+0.0235 * 1.316+ \\
& 0.6902 * 2.139+0.1258 * 3.117+ \\
& 0.0072 * 4.561+0.0 * 7.900+ \\
& 0.1534 * 20.169 \\
& =0.5674 * 0.534+0.1109 * 1.108+ \\
& 0.045 * 1.701+0.0 * 2.452+ \\
& 0.0 * 3.380+0.2767 * 5.082+ \\
& 0.0 * 7.980 \\
& =1.9086 \mathrm{~g} / \mathrm{t} \\
& \ldots+\mathrm{ph}_{\text {bin7 }} * \mathrm{Au}_{\text {bin } 7} \\
& =0.3238 * 0.109+0.0 * 0.492+
\end{aligned}
$$

Porphyry grade $($ au_py $)=$ py $_{\text {bin } 1} * \mathrm{Au}_{\mathrm{bin} 1}+\mathrm{py}_{\mathrm{bin} 2} * \mathrm{Au}_{\mathrm{bin} 2}+$

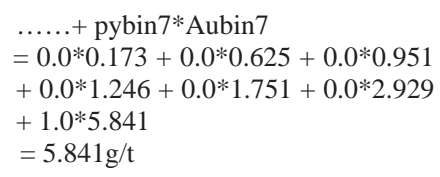

where Au represent the applicable gold grade for the bins.

The average grade "au" of the cell in the block model is given by,

$$
\begin{gathered}
a u=\frac{q v_{-} p r o p * a u_{-} q v}{q v_{-} p r o p+p s_{-} p r o p+p h_{-} p r o p+p y_{-} p r o p}+\frac{p s_{-} p r o p * a u_{-} p s}{q v_{-} p r o p+p s_{-} p r o p+p h_{-} p r o p+p y_{-} p r o p} \\
+\frac{p h_{-} p r o *^{*} a u_{-} p h}{q v_{-} p r o p+p s_{-} p r o p+p h_{-} p r o p+p y_{-} p r o p}+\frac{p y_{-} p r o *^{*} a u_{-} p y}{q v_{-} p r o p+p s_{-} p r o p+p h_{-} p r o p+p y_{-} p r o p} \\
q v_{-} \text {prop }+ \text { ps_prop }+ \text { ph_prop }+ \text { py_prop }=0.1504+0.2652+ \\
=0.5169+0.0222 \\
=0.9547
\end{gathered}
$$

Hence average grade “au” will be,

$$
\begin{gathered}
a u=\frac{0.1504 * 5.0261}{0.9547}+\frac{0.2652 * 1.9086}{0.9547}+\frac{0.5169 * 1.2788}{0.9547}+\frac{0.0222 * 5.8410}{0.9547} \\
=2.1502 \mathrm{~g} / \mathrm{t}
\end{gathered}
$$

Therefore, the average gold grade of the cell is $2.15 \mathrm{~g} / \mathrm{t}$.

\section{Authors}

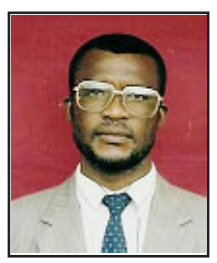

Al-Hassan is a Senior Lecturer in Mining Engineering at the University of Mines and Technology, Tarkwa. He is currently the Dean of Students. He obtained his BSc (Hons.) and Postgraduate Diploma in Mining Engineering degrees from the University of Mines and Technology in 1982 and 1983 respectively. He was the Dean, Faculty of Engineering and the Head of the Electrical Engineering Department. He worked as a Mining Engineer at Tarkwa Goldfields Ltd. until 1987 when he joined the University as a Lecturer. He obtained his PhD degree from the University of Wales, Cardiff, UK in 1994. His areas of specialisation include Mineral Reserve Estimation, Mine Planning and Design, Mineral Economics and Computer Applications.

\section{Aboagye}

